\title{
Distribution of the deep-sea genus Bathypterois (Pisces: Ipnopidae) in the Eastern Central Pacific
}

\author{
Edgar Cruz-Acevedo ${ }^{1}$, Miguel Betancourt-Lozano ${ }^{2}$ \& Hugo Aguirre-Villaseñor ${ }^{3}$
}

1. Programa de Doctorado en Ciencias, Centro de Investigación en Alimentación y Desarrollo, A.C., Avenida SábaloCerritos S/N, Mazatlán 82100, Sinaloa, México; edgar.cruz@estudiantes.ciad.mx

2. Centro de Investigación en Alimentación y Desarrollo, A.C., Avenida Sábalo-Cerritos S/N, Mazatlán 82100, Sinaloa, México; mbl@ciad.mx

3. Instituto Nacional de Pesca, Centro Regional de Investigación Pesquera-Mazatlán, Calzada Sábalo-Cerritos S/N, Mazatlán 1177, Sinaloa, México; hugo.aguirre@inapesca.gob.mx

Received 12-IV-2016. Corrected 18-VII-2016. $\quad$ Accepted 24-VIII-2016.

\begin{abstract}
The genus Bathypterois (tripod fish) comprises 19 species of deep-sea fishes distributed worldwide. The biology and distribution of the species of this genus are relatively poorly known throughout the Eastern Central Pacific (ECP). This work aims to update the geographic and bathymetric distribution of species of Bathypterois throughout the ECP. To describe the influence of depth, temperature and dissolved oxygen concentrations (DO) on latitudinal and depth distribution of members of the genus throughout the Mexican Pacific, 51 specimens of $B$. atricolor (12 trawls) and 112 of $B$. ventralis (18 trawls), collected during TALUD project, were analyzed. Bathypterois atricolor had broader environmental niches (depth: 0.47, temperature: 0.46, DO: 0.39), and inhabits deeper and colder sites (Electivity positives: $>1000 \mathrm{~m},<3.2^{\circ} \mathrm{C}, 1.0-1.62 \mathrm{~mL} / \mathrm{L}$ ) than B. ventralis, which had narrow environmental niches (depth: 0.34, temperature: 0.32 , DO: 0.28 ), with high affinity to warmer sites and lower DO concentrations (Electivity positives: $778-1400 \mathrm{~m}, 3.3-5.8{ }^{\circ} \mathrm{C},<1.0 \mathrm{~mL} / \mathrm{L}$ ). Both species used different environmental strata (niche overlap; depth: 0.34, temperature: 0.32, DO: 0.28). The adaptation of $B$. atricolor to live in a broad range of DO concentrations explains its almost circumglobal distribution, while $B$. ventralis lives almost permanently in the Oxygen Minimum Zone $(<0.05 \mathrm{~mL} / \mathrm{L})$, so the $\mathrm{DO}$ could be a limiting factor, reducing its potential geographic and bathymetric distributions. None of these species had been previously recorded in the central Gulf of California, and B. ventralis had not been recorded along the West coast of Baja California. This study confirms that both species have a continuous distribution within the ECP, our new records extended the known northernmost range for B. atricolor by $886 \mathrm{~km}$ (from $22^{\circ} 46^{\prime} \mathrm{N}$ to $30^{\circ} 45^{\prime} \mathrm{N}$ ) and for $B$. ventralis by $645 \mathrm{~km}$ (from $21^{\circ} 18^{\prime} \mathrm{N}$ to $27^{\circ} 07^{\prime} \mathrm{N}$ ). Rev. Biol. Trop. 65 (1): 89-101. Epub 2017 March 01.
\end{abstract}

Key words: TALUD project, Mexican Pacific, environmental factors, tripod fish, environmental niche, univariate and multivariate approaches, distribution.

The genus Bathypterois Günther, 1878 (Pisces: Ipnopidae) comprises 19 species of benthic deep-sea fishes widely distributed in the world ocean, but without commercial importance. Species of this genus are mainly bathydemersal, hermaphrodite and feed on small invertebrates (Sulak, 1977). Most of them have few records and $B$. mediterraneus Bauchot 1962, endemic of the Mediterranean Sea, has the most complete data on its biology and distribution (D’onghia et al., 2004).
In the Eastern Pacific (EP), four species of the genus have been recorded: $B$. atricolor Alcock, 1896 from Chile to the tip of the Baja California peninsula, including the Southern Gulf of California $\left(32^{\circ} 08^{\prime} \mathrm{S}-23^{\circ} 58^{\prime} \mathrm{N}\right) ; B$. ventralis Garman, 1899 from Chile to the tip

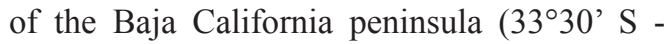
$\left.21^{\circ} 18^{\prime} \mathrm{N}\right)$; B. longipes Günther, 1878 from off Panama $\left(06^{\circ} 52^{\prime} \mathrm{N}\right)$ and a juvenile specimen from off USA (Between $30^{\circ} \mathrm{N}-40^{\circ} \mathrm{N}$ and $\left.130^{\circ} \mathrm{W}-140^{\circ} \mathrm{W}\right) ;$ B. pectinatus Mead, 1959 
from Chile to Panama $\left(20^{\circ} \mathrm{S}-07^{\circ} 24^{\prime} \mathrm{N}\right)$. In the Central Pacific, B. grallator (Goode \& Bean, 1886) was recorded close to the Hawaiian Islands $\left(20^{\circ} 34^{\prime} \mathrm{N}, 156^{\circ} 05^{\prime} \mathrm{W}\right.$; $20^{\circ} 35^{\prime} \mathrm{N}$, $156^{\circ} 05^{\prime}$ W; $19^{\circ} 38^{\prime} \mathrm{N}, 156^{\circ} 04^{\prime} \mathrm{W}$ ) (Sulak, 1977; Jones \& Sulak, 1990).

The biology and distribution of the genus Bathypterois in the EP are relatively poorly known, mainly because of scarcity of specimens and field observations (Angulo, Bussing \& López, 2015). Abiotic factors, such as depth, temperature, dissolved oxygen concentrations (DO), pressure, organic carbon concentration, substrate and physical barriers could determine the geographic and bathymetric distribution of the species, both regionally and locally (Watling, Guinotte, Clark, \& Smith, 2013). The depth and temperature affect the geographic and vertical distribution of the Bathypterois species, although, the influence of DO in their distribution patterns has not been evaluated (Sulak, 1977). An Oxygen Minimum Zone (OMZ) is an area with low concentrations of DO $(<0.5 \mathrm{~mL} / \mathrm{L})$, limiting the distribution of many mesopelagic and benthic species (Levin, 2003). The OMZ of the Pacific Ocean is the most pronounced worldwide (Fiedler \& Talley, 2006). Throughout the Mexican Pacific, many species of deep sea shrimps (Hendrickx \& Serrano, 2010), mollusks (Zamorano, Hendrickx, \& Toledano, 2006), Polychaetes (Mendez, 2007) and fishes (Levin, 2003) are distributed at established depth ranges, living above or below the OMZ, while some of them are able to live within the OMZ or perform vertical migrations through it.

The Mexican Pacific comprises three mayor regions: The West coast of the Baja California peninsula (BC), a transitional zone in faunal composition and environmental conditions (Rodríguez-Romero, Palacios-Salgado, López-Martínez, Hernández-Vázquez, \& Ponce-Díaz, 2008), influenced by the California Current, the subsurface California Countercurrent and the North Equatorial current (OMZ: 300 - 1800 m depth) (Levin, 2003; Fiedler \& Talley, 2006). The Gulf of California (GC) is a semi-closed sea, with strong processes of horizontal transport and vertical mixing of water in its Northern part (Palacios-Hernández, Beier, Lavín, \& Ripa, 2002), while in its central and southernmost portions, the OMZ is located between 250 and $1400 \mathrm{~m}$ depth, and between 70 and $1300 \mathrm{~m}$ depth, respectively, with a hypoxic-anoxic zone (150-700 $\mathrm{m}$ depth), being an impenetrable barrier for some species (Zamorano et al., 2006; Mendez, 2007; Hendrickx \& Serrano, 2010). The Southwest Coast of Mexico (SCM) belongs to the ECP and is influenced in its northernmost portion by the California Current, while in its central and southernmost portions it is influenced by tropical water masses from the North Equatorial and Costa Rica Currents (Kessler, 2006).

The objective of this work is to update the geographic and bathymetric distribution of the species of Bathypterois throughout the ECP and to describe the influence of depth, temperature and DO concentrations on the distribution and abundance of $B$. atricolor and B. ventralis throughout the Mexican Pacific, using both univariate and multivariate approaches.

\section{MATERIAL AND METHODS}

\section{Review of geographical distribution:} Historical records of genus Bathypterois were obtained from scientific papers (Sulak, 1977; Angulo et al., 2015) and biodiversity databases: Ocean Biogeographic Information System (http://www.iobis.org/), Global Biodiversity Information Facility (http://www.gbif.org/) and Fishnet 2 (http://www.fishnet2.net/). The online databases of the following scientific collections were also consulted: American Museum of Natural History (http://sci-web-001.amnh.org/ db/emuwebamnh/Query.php), Natural History Museum Los Angeles County (http://www. nhm.org/site/research-collections/ichthyology), California Academy of Science (http:// collections.calacademy.org/ich/), Scripps Institution of Oceanography (https://scripps.ucsd. edu/collections/mv) and Smithsonian National Museum of Natural History (http://collections. nmnh.si.edu/search/fishes/). These records 
were complemented with those obtained during the TALUD Project.

TALUD project: This project has been developed since 1989 to date by the Instituto de Ciencias del Mar y Limnología from the Universidad Nacional Autónoma de México, aboard the R/V "El Puma". It aims to study the faunal composition of the continental slope of the Mexican Pacific, including measurements of environmental factors (Hendrickx, 2012). Specimens of genus Bathypterois were collected from eight of 14 TALUD cruises (Table 1, Fig. 1; Project's extreme coordinates: $16^{\circ} 49^{\prime} \mathrm{N}-31^{\circ} 48^{\prime} \mathrm{N}, 100^{\circ} 21^{\prime} \mathrm{W}-117^{\circ} 15^{\prime} \mathrm{W}$ ). The sampling device was an epibenthic sledge ( $2.35 \mathrm{~m}$ wide, $0.90 \mathrm{~m}$ high) equipped with a collecting net of about $5.5 \mathrm{~cm}$ stretched mesh size, operated at depths from 778 to $2102.5 \mathrm{~m}$. The average of fishing operation was $30 \mathrm{~min}$, at a ship speed of 2 knots. Sampling depth was estimated with an analogical Edo Western echo sounder. Temperature and DO concentrations were measured approximately $10 \mathrm{~m}$ above the bottom with a CTD (Seabird 19). Specimens were fixed with a $4 \%$ formaldehyde seawater solution for at least one week, washed with tap water and preserved in $70 \%$ ethanol. All specimens were deposited in in the reference Fish collection of the Instituto de Ciencias del Mar y Limnología, Unidad Académica Mazatlán; the catalogue numbers are detailed in the Supplementary material. The Bray-Curtis index was calculated to define environmental strata (depth, temperature and DO). All data were transformed to square root to analyze the degree of similarity between the sampling stations, using the PRIMER Ver. 6 software (Clarke \& Warwick, 2001). Stations strata were considered above $80 \%$ of similarity.

Species identification and size distribution: Fishes were identified using Sulak's (1977) key. Vertebral counts were obtained from X-rays images from a specimen of each species (B. atricolor and B. ventralis) and of one undetermined specimen. All measurements were taken using a dial caliper $( \pm 0.05 \mathrm{~mm})$. Total weight (TW) was obtained using an analytical balance $( \pm 0.005 \mathrm{~g})$. All measurements

TABLE 1

Trawls with records of Bathypterois specimens during TALUD Project

\begin{tabular}{|c|c|c|c|c|c|c|c|c|c|}
\hline TALUD & Area & Date Month/year & Trawls & With fishes & With Bathypterois & $\mathrm{Bat}^{1}$ & $\mathrm{Bve}^{2}$ & Both $^{3}$ & $\mathrm{Bsp}^{4}$ \\
\hline IV & $\mathrm{GC}$ & $08 / 2000$ & 8 & 7 & 2 & - & 2 & - & - \\
\hline $\mathrm{V}$ & GC & $12 / 2000$ & 13 & 8 & 0 & - & - & - & - \\
\hline VI & $\mathrm{GC}$ & $03 / 2001$ & 7 & 6 & 1 & - & 1 & - & - \\
\hline VII & GC & $06 / 2001$ & 14 & 14 & 2 & 1 & 1 & - & - \\
\hline VIII & $\mathrm{GC}$ & $04 / 2005$ & 13 & 10 & 2 & 2 & - & - & - \\
\hline IX & $\mathrm{GC}$ & $11 / 2005$ & 17 & 9 & 1 & - & 1 & - & - \\
\hline $\mathrm{X}$ & $\mathrm{GC}$ & $02 / 2007$ & 21 & 20 & 0 & - & - & - & - \\
\hline XI & SCM & $06 / 2007$ & 1 & 1 & 0 & - & - & - & - \\
\hline XII & $\mathrm{SCM}$ & $03 / 2008$ & 17 & 17 & 9 & 4 & 5 & - & - \\
\hline XIII & $\mathrm{GC}$ & $01 / 2009$ & 4 & 4 & 0 & - & - & - & - \\
\hline XIV & GC & $04 / 2011$ & 26 & 24 & 0 & - & - & - & - \\
\hline XV & $\mathrm{BC}$ & $08 / 2012$ & 28 & 22 & 9 & 4 & 8 & 3 & 1 \\
\hline XVI & $\mathrm{BC}$ & $07 / 2013$ & 2 & 2 & 0 & - & - & - & - \\
\hline XVI-B & $\mathrm{BC}$ & $05 / 2014$ & 23 & 23 & 1 & 1 & - & - & - \\
\hline Total & & & 194 & 167 & 27 & 12 & 18 & 3 & 1 \\
\hline
\end{tabular}

1. Bat = Bathypterois atricolor .

2. $\mathrm{Bve}=$ Bathypterois ventralis.

3. Both $=$ both species.

4. Bsp $=$ Bathypterois $\mathrm{sp}$. 


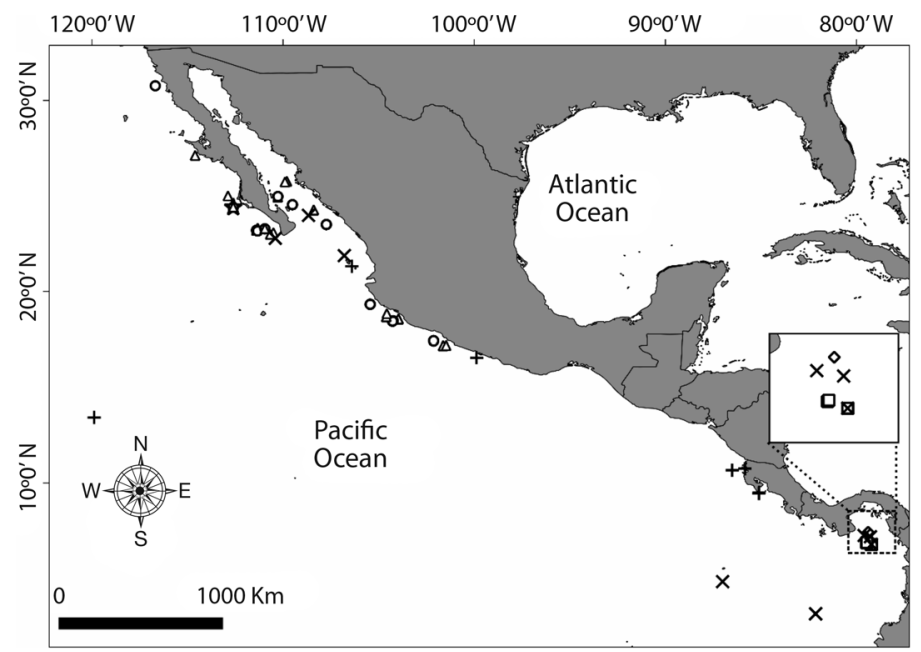

Fig. 1. Geographic distribution of Bathypterois species along the Eastern Central Pacific. TALUD records: B. atricolor (open circles), B. ventralis (open triangles) and the Bathypterois sp. (open star). Previous records: B. atricolor (cross), B. longipes (open square), B. pectinatus (open rhombus), B. ventralis (plus).

and meristic data obtained from specimens were summarized in table 2 and compared with those compiled by Sulak (1977). A standard length (SL) frequency histogram was constructed for each species (class interval size of $10 \mathrm{~mm}$ ) and normality was tested using a Kolmogorov-Smirnov test (D) (Zar, 1999). The SL-TW relationship was adjusted to a potential curve, the slope (b) values was compared both, with the theoretical isometric growth $(b=3)$ and between species using a t-test. Species relative abundances (RA) were estimated from the number of captured specimens in each station per filtered water volume unity (individuals $/ 1000 \mathrm{~m}^{3}$ ). Analyses were done using Microsoft Excel® 2013, and significance for all tests was 0.05 .

Relationship between environmental factors and species distribution: Pearson's correlation was used to describe the relationships between environmental factors (depth, temperature and DO), and between each factor regarding to the SL. A series of univariate analyzes were performed in order to evaluate the effect of each environmental variable alone on the distribution of species. The Levin's standardized niche breadth $(\mathrm{Ba})$ was calculated to estimate the proportion of resources used by each species, $(0=$ high specialization; 1 $=$ all strata are used in the same proportion) (Krebs, 1999). The Pianka's niche overlap index modified by MacArthur and Levins was used to measure the ratio of a resource shared by both species, $(0=$ no resources used in common; 1 = complete overlap) (Krebs, 1999). The Electivity index (E) of Ivlev (1961) was also used to analyze the affinity of the species to environmental strata calculated by Bray-Curtis index $(-1=$ total aversion; $0=$ no choice; $1=$ total affinity). Analyses were performed using Microsoft Excel ${ }^{\circledR} 2013$.

To determine the main factors influencing species distribution in the study area, a canonical correspondence analysis (CCA) was performed in the CANOCO 4.5 software (Lepš \& Šmilauer, 2003), for dependent (species, RA transformed to "square root*pi") and independent data (depth, temperature and DO; all transformed to $\log +1)$.

\section{RESULTS}

Review of geographical distribution: Throughout the ECP, 17 historical records of Bathypterois have been reported (Fig. 1), 
TABLE 2

Body measurements and meristic characters taken from Bathypterois species

\begin{tabular}{|c|c|c|c|c|c|}
\hline \multirow[b]{2}{*}{ Measurements ${ }^{1}$} & \multicolumn{2}{|c|}{ B. atricolor ${ }^{2}$} & \multicolumn{2}{|c|}{ B. ventralis ${ }^{2}$} & Bathypterois sp.*** \\
\hline & TALUD & Previous records ${ }^{3}$ & TALUD & Previous records ${ }^{3}$ & TALUD \\
\hline Total weight (g) (TW) & $1.7-20.4(9.3 \pm 4.2)$ & - & $1.9-29.5(9.8 \pm 4.8)$ & - & 8.4 \\
\hline Standard length (mm) (SL) & $73-161(120 \pm 16.9)$ & $69-204$ & $81-167(115.7 \pm 15.3)$ & $85-150$ & 118 \\
\hline Head length (HDL)* & $21.6-30.5(24.5 \pm 1.3)$ & $20.0-25.2$ & $21.5-26.8(24.5 \pm 1)$ & $20.6-24.4$ & 24.8 \\
\hline Pre-first dorsal fin length* & $41.3-47.9(44.6 \pm 1.3)$ & $40.5-46.3$ & $40.3-48.1(44.5 \pm 1.3)$ & $42.8-46.8$ & 44.5 \\
\hline Pre-second dorsal fin length* & $71.3-79.7(76.2 \pm 1.8)$ & - & $64.8-82.2(75.9 \pm 2.1)$ & - & 77.2 \\
\hline Body Height* & 8-13.2 (10.8 \pm 1$)$ & - & $8.6-14.2(11.3 \pm 1.1)$ & - & 9.8 \\
\hline Eye length** & $4.4-9.0(6.6 \pm 1)$ & - & $5.7-8.6(6.8 \pm 0.6)$ & - & 5.8 \\
\hline Pre-orbital length** & $29.8-39.5(34.3 \pm 2.1)$ & - & $27.4-40.4(34.5 \pm 2.8)$ & - & 31.1 \\
\hline Pre-pelvic fin length* & $35.3-40.3(38.1 \pm 1.2)$ & $35.4-42.2$ & $32.7-41.3(37.7 \pm 1.5)$ & $35.2-39.6$ & 38.6 \\
\hline Pre-anus length* & $47.8-52.9(50.4 \pm 1.1)$ & - & $46.6-54(50.1 \pm 1.4)$ & - & 50.6 \\
\hline Pre-anal length* & $55.1-62.5(58.8 \pm 1.9)$ & $56.7-63.6$ & $56.1-62.6(58.9 \pm 1.3)$ & $54.2-62.9$ & 60.8 \\
\hline Length of longest produced pelvic ray* & $24-64.4(39.8 \pm 9.8)$ & $24.5-57.8$ & $21.1-67.8(43.5 \pm 11.3)$ & $39.1-59.4$ & 31.4 \\
\hline Length of longest lower caudal ray* & $17.3-37.7(26.5 \pm 4.4)$ & $14.8-33.3$ & $22.9-55.9(29.1 \pm 5.4)$ & $32.7-44.6$ & 22.6 \\
\hline Length of longest produced pectoral ray* & $63.8-98.3(75.9 \pm 8.3)$ & $81.4-189$ & $59.8-98.8(74.7 \pm 7.8)$ & $101-103$ & 79.5 \\
\hline \multicolumn{6}{|l|}{ Counts } \\
\hline Dorsal fin rays & $12-14$ & $13-16$ & $12-14$ & $12-14$ & \\
\hline Anal fin rays & 8-11 & $8-10$ & $8-11$ & $9-10$ & \\
\hline Pelvic fin rays & 9 & 9 & 9 & 9 (rarely 10) & \\
\hline Pectoral fin rays visible externally & $12-13$ & $12-13$ & $14-16$ & $14-16$ & Left: 13 Right: 14 \\
\hline Pectoral fin rays lower part & $10-11$ & $10-11$ (9 once) & $12-14$ & $12-14$ & Left: 11 Right: 12 \\
\hline Caudal fin rays (dorsal + ventral) & iv-v $10+9$ iv-v & iv-v $10+9$ iv-v & v-vi $10+9$ iv-v & v-vi $10+9$ iv-v & v $10+9$ iv \\
\hline Gill rakers & $12-15+1+29-32$ & $11-14+1+27-33$ & $12-14+1+29-34$ & $12-14+1+30-32$ & $13+1+31$ \\
\hline Branchiostegal rays & $12-15$ & $12-14$ & $12-15$ & 13 & 13 \\
\hline Lateral line scales & $57-65$ & $57-62$ & $56-64$ & $57-59$ & 60 \\
\hline Vertebrae (incl. urostyle) & $56^{* * *}$ & $54-57$ & $55^{* * *}$ & $52-56$ & 56 \\
\hline Dorsal-fin origin over vertebra & $24 * * *$ & $21-25$ & $22 * * *$ & $21-23$ & 21 \\
\hline Anal-fin origin under vertebra & $33 * * *$ & $32-35$ & $32 * * *$ & $31-34$ & 32 \\
\hline
\end{tabular}

$1 *=$ Percent of SL, $* *=$ Percent of HDL, $* * *=$ One specimen.

${ }^{2}$ Measurements and counts are shown as minimum-maximum, mean \pm standard deviation were in parenthesis, following those of Sulak (1977).

${ }^{3}$ Sources: Sulak (1977); Angulo et al., (2015).

$B$. atricolor (eight records) and B. ventralis (five records) were the only species recorded in the Mexican Pacific, while $B$. longipes (three records) and $B$. pectinatus (a single record) were recorded off Panama.

TALUD project: A total of 194 deep benthic trawls were carried out ( $>200 \mathrm{~m}$ depth). In 27 trawls of eight cruises, 164 specimens of Bathypterois were caught (Table 1). Two species were recorded: B. atricolor $(\mathrm{n}=51$,
12 trawls) and $B$. ventralis $(\mathrm{n}=112,18$ trawls $)$ (see Supplementary material). These species were caught together only in three trawls. One specimen captured with both species (TALUD $\mathrm{XV}$, Station 8, $1227 \mathrm{~m}$ ), was recorded as undetermined, because it showed intermediate counts in the number of rays in the lower part of the pectoral fin (left: 11, right: 12 rays), being the feature used to differentiate $B$. atricolor (10-11 rays) from $B$. ventralis (12-14 rays) (Table 2). The specimen of Bathypterois sp. 
resembles in almost all the measurements and counts those proposed for both Bathypterois species, except for the ratio "Length of longest lower caudal ray/SL" ratio, which matches the interval established for $B$. atricolor but not for $B$. ventralis. The Bray-Curtis similarity index (Fig. 2) classified five strata for depth (similarities: 91-96\%; group 1: $778 \mathrm{~m}$, group 2:
930-1 $116 \mathrm{~m}$, group 3: 1170-1290 m, group 4: 1406-1629m, group 5: 1869-2012.5 m), five strata for temperature (similarities: 88-96\%; group 1: $2.13-2.46{ }^{\circ} \mathrm{C}$, group 2: $2.82-3.02{ }^{\circ} \mathrm{C}$, group 3: $3.28-3.75{ }^{\circ} \mathrm{C}$, group $4: 3.98-4.71^{\circ} \mathrm{C}$, group 5: $5.75^{\circ} \mathrm{C}$ ) and six strata for DO (similarities: $82-93 \%$; group 1: $0.11 \mathrm{~mL} / \mathrm{L}$, group 2: $0.21-0.28 \mathrm{~mL} / \mathrm{L}$, group 3: $0.38-0.43 \mathrm{~mL} / \mathrm{L}$,
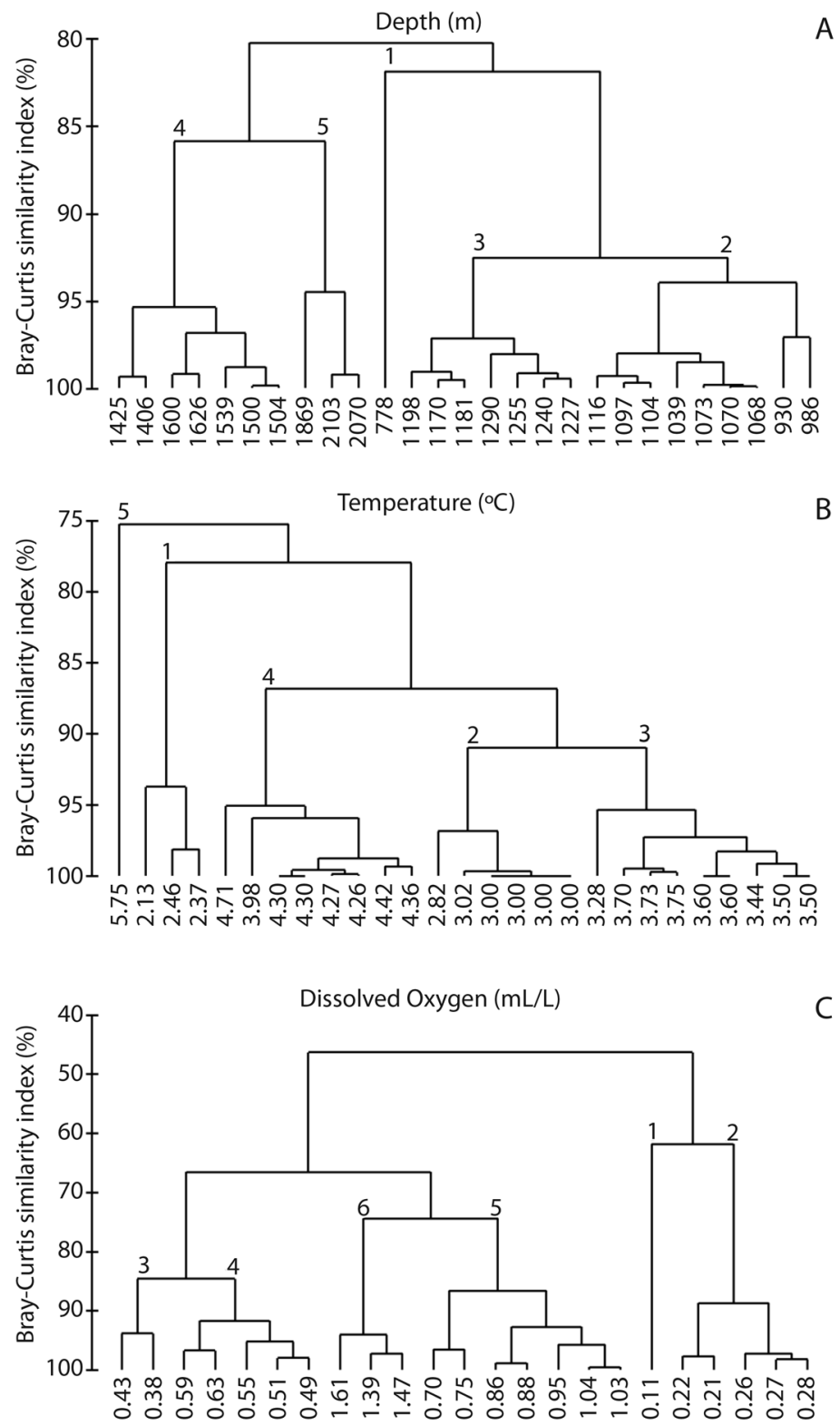

Fig. 2. Dendrogram for environmental data set based on the Bray-Curtis similarity index using the unweighted group average link. A. Depth; B. temperature; C. dissolved oxygen. 
group 4: 0.49-0.63 mL/L, group 5: 0.7-1.04 $\mathrm{m} / \mathrm{L} / \mathrm{L}$, group 6: 1.39-1.61 mL/L).

Size distribution: The size-range of $B$. atricolor was $73-161 \mathrm{~mm} \mathrm{SL}$ and for $B$. ventralis was 81-167 mm SL (Fig. 3). The most abundant size class for B. atricolor was 120$130 \mathrm{~mm}$ SL (mean: $120 \pm 17 \mathrm{~mm}$ ) and 110-120 mm SL (mean: $116 \pm 15 \mathrm{~mm}$ ) for $B$. ventralis. Both species had similar SL $(\mathrm{t}=1.62, \mathrm{p}=0.11)$ and showed size frequencies adjusted to normal distributions $(B$. atricolor: $\mathrm{D}=0.07, \mathrm{p}>0.20$; $B$. ventralis: $\mathrm{D}=0.06, \mathrm{p}>0.20)$.

Relationship between environmental factors and species distribution: The temperature decreased with depth $(r=-0.93, \mathrm{p}<$ 0.01). The OMZ was located between $778 \mathrm{~m}$ and $1200 \mathrm{~m}$ depth, increasing concentrations of DO at greater depths $(r=0.96, \mathrm{p}<0.01)$. Temperature and DO had a negative correlation $(r=-0.94, \mathrm{p}<0.01)$. Bathypterois atricolor had not significant correlation for SL respect to depth $(\mathrm{r}=0.23, \mathrm{p}=0.10)$, temperature $(\mathrm{r}=$ $-0.27, \mathrm{p}=0.06)$ and DO $(\mathrm{r}=0.25, \mathrm{p}=0.09)$, however, the largest individuals of $B$. ventralis were found in deeper trawls $(\mathrm{r}=0.22, \mathrm{p}=0.02)$ (Fig. 4A), with lower temperatures $(\mathrm{r}=-0.23, \mathrm{p}$ $=0.02$ ) (Fig. 4B) and higher concentrations of DO $(\mathrm{r}=0.36, \mathrm{p}<0.01)$ (Fig. 4C). The SL - TW relationship showed that $B$. atricolor (potential expected: $\left.\mathrm{y}=1 \mathrm{E}-06 \mathrm{x}^{3.3} ; \mathrm{t}=-2.81, \mathrm{p}<0.01\right)$ and
B. ventralis (potential expected: $\mathrm{y}=1 \mathrm{E}-06 \mathrm{x}^{3.5}$; $\mathrm{t}=-4.10, \mathrm{p}<0.01)$ displayed positive allometric growth, distinct from an isometric growth. Both species had similar SL - TW relationships to each other $(\mathrm{t}=0.27, \mathrm{p}=0.78)$.

The niche breadth values for $B$. atricolor were: depth $=0.47$, temperature $=0.46, \mathrm{DO}=$ 0.39 , and for $B$. ventralis were: depth $=0.24$, temperature $=0.33$, DO $=0.28$. The niche overlap were: depth $=0.34$, temperature $=$ 0.32 and $\mathrm{DO}=0.28$. Bathypterois atricolor showed positive values of the environmental electivity index of Ivlev (E) at depths greater than $1000 \mathrm{~m}$ (Fig. 5A), while for temperature this species had a positive affinity at colder sites $\left(<3.2^{\circ} \mathrm{C}\right)($ Fig. $5 \mathrm{~B})$ with low to high DO values (1.0-1.62 mL/L) (Fig. 5C). Bathypterois ventralis had positive values of "E" at depths between 778 and $1400 \mathrm{~m}$ (Fig. 5A), with high affinity to warmer sites $\left(3.3-5.8{ }^{\circ} \mathrm{C}\right)$ (Fig. 5B) and $\mathrm{DO}$ concentrations $<1.0 \mathrm{~mL} / \mathrm{L}$ (Fig. $5 \mathrm{C}$ ).

The CCA showed a differential spatial distribution for Bathypterois species (Fig. 6). $71.5 \%$ of the species-environment distribution variance is explained by the first canonical axis (eigenvalue $=0.519$ ) and $28.5 \%$ by the second canonical axis (eigenvalue = 0.207). Bathypterois atricolor was related to deeper and colder sites, with DO concentrations above $1.0 \mathrm{~mL} / \mathrm{L}$. Bathypterois ventralis was strongly influenced by shallower sites, with lower DO concentrations and warmer

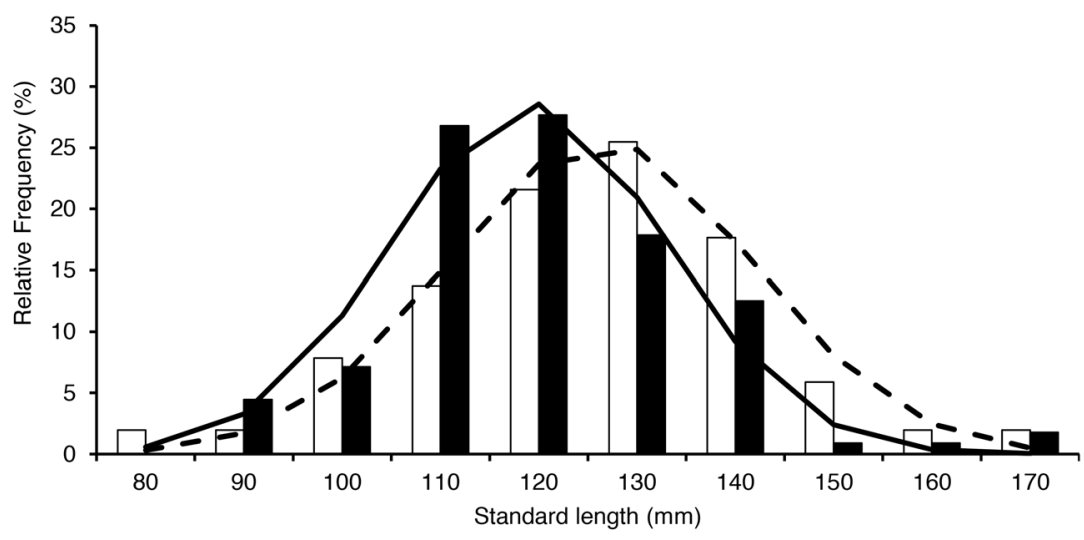

Fig. 3. Size frequency for $B$. (Observed: Open bars, normal distribution expected: dotted line) and $B$. ventralis (Observed: Black bars, normal distribution expected: continuous line). 

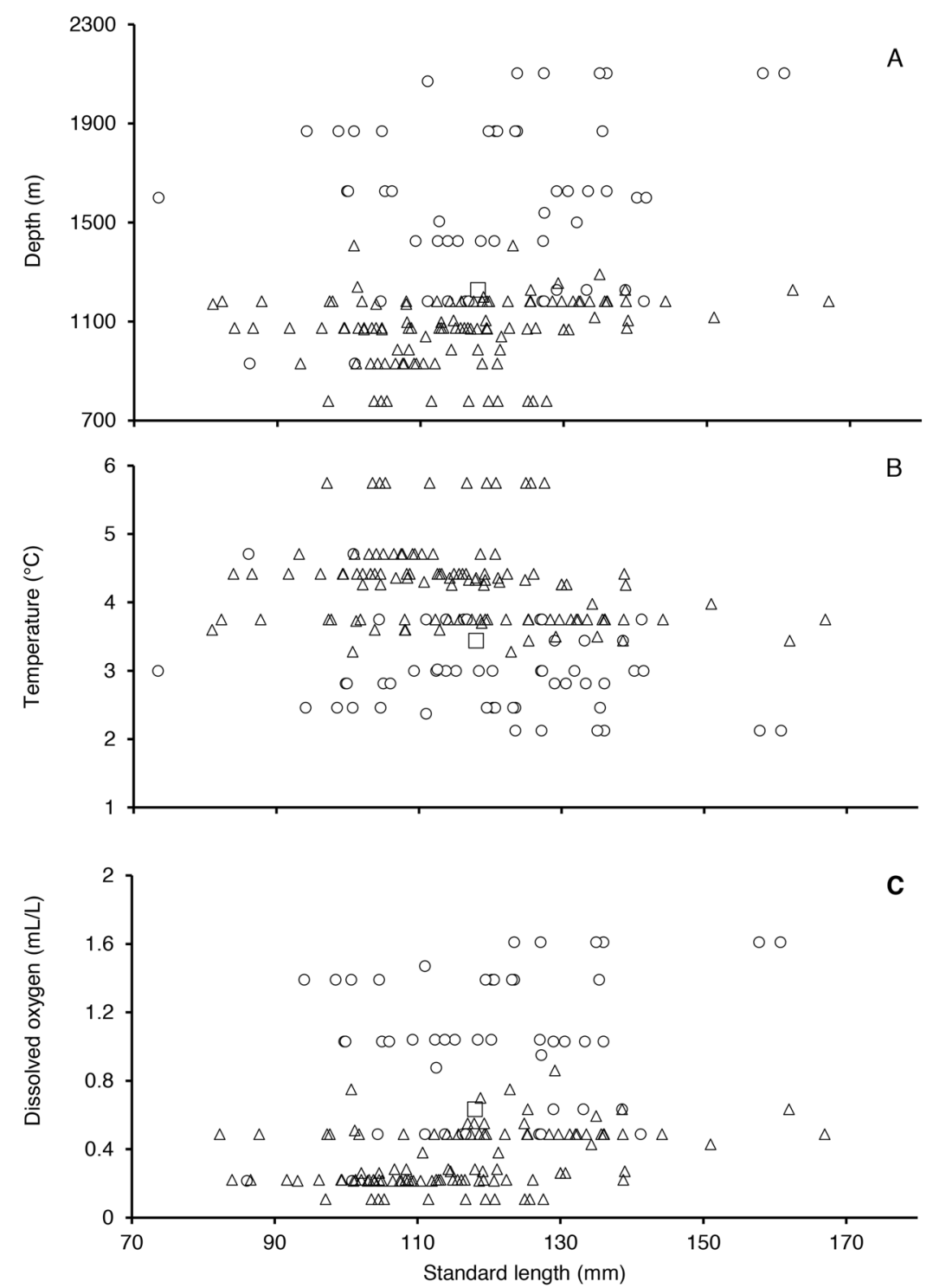

Fig. 4. Relationship between environmental factors and Standard length for B. atricolor (open circles), B. ventralis (open triangles) and the Bathypterois sp. (open squares). A. Depth; B. temperature; C. dissolved oxygen.

temperatures. A high correlation was found between species-environment distribution for the first axis $(r=0.85)$.

\section{DISCUSSION}

This study confirms that $B$. atricolor and B. ventralis have a continuous distribution within the ECP, providing the first record for both species in the central $\mathrm{GC}$ and for $B$. ventralis in the $\mathrm{BC}$, extending their Northern distribution $\left(B\right.$. atricolor: from $22^{\circ} 46^{\prime} \mathrm{N}$ to $30^{\circ} 45^{\prime} \mathrm{N}, 886 \mathrm{~km} ; B$. ventralis: from $21^{\circ} 18^{\prime} \mathrm{N}$ to $27^{\circ} 07^{\prime} \mathrm{N}, 645 \mathrm{~km}$ ).

Bathypterois grallator $(878-3492 \mathrm{~m}, 2.7-$ $\left.13.5^{\circ} \mathrm{C}\right)$ and $B$. pectinatus $(700-2100 \mathrm{~m}$, 

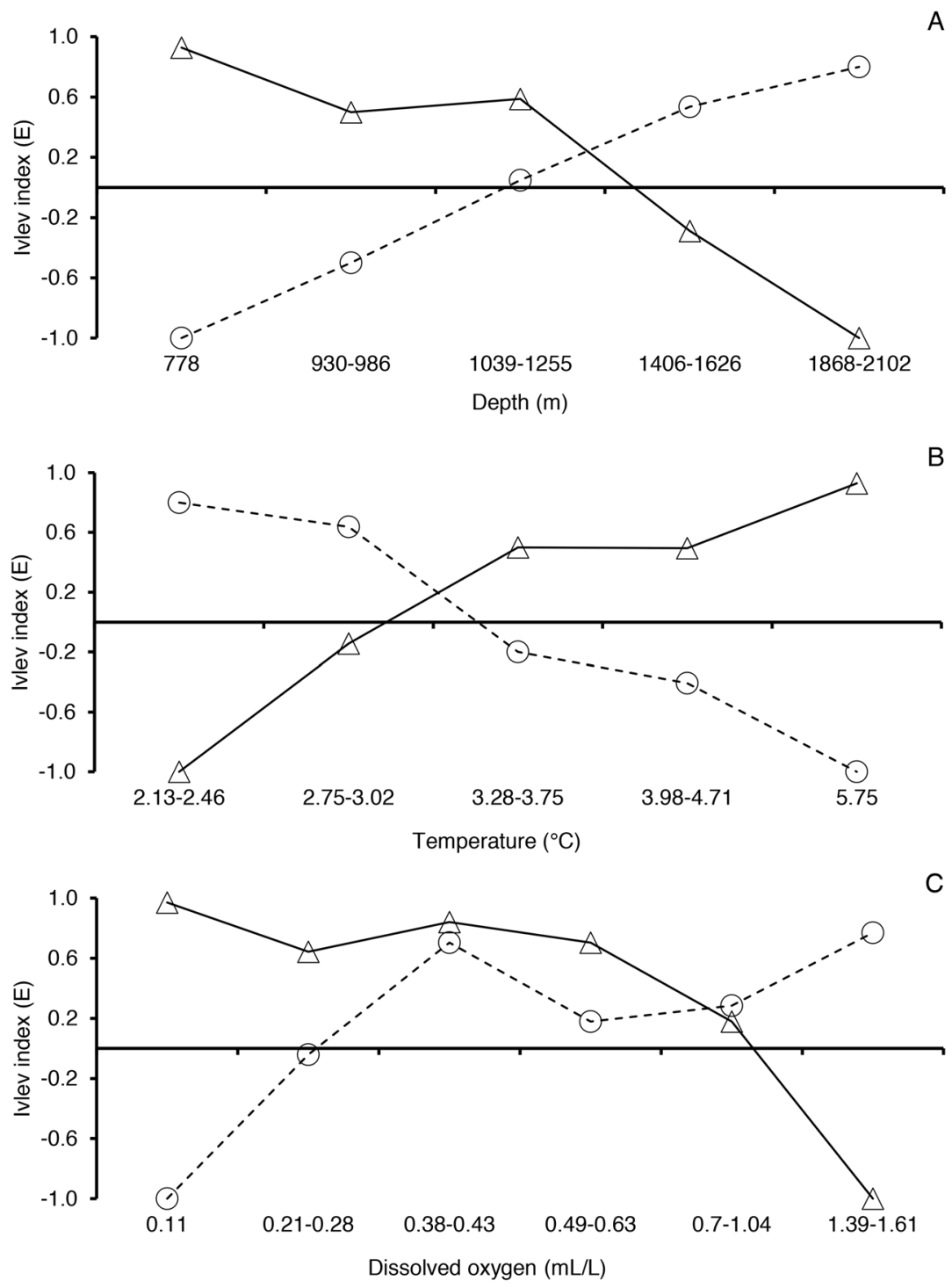

Fig. 5. Environmental Electivity index of Ivlev (E) for B. atricolor, (Open circles, dotted line) and B. ventralis (open triangles, continuous line). A. Depth; B. temperature; C. dissolved oxygen.

2.9-3.7 ${ }^{\circ} \mathrm{C}$ ) inhabit similar depth and temperature intervals to those sampled during TALUD Project (200-2 $\left.330 \mathrm{~m} ; 1.9-14.8{ }^{\circ} \mathrm{C}\right)$, however these species were not recorded throughout this project. The Northern records for both species throughout the EP matches with the "Costa Rican Dome", an environmental transition zone off Central America $\left(9^{\circ} \mathrm{N}-10^{\circ} \mathrm{N}\right)$, characterized by convergent water masses from the South and North Pacific and deep water vertically moved to the surface $(0-2500 \mathrm{~m})$, producing an upwelling zone that may be is a physiological barrier for the latitudinal distribution of these species (Sulak, 1977; Fiedler \& Talley, 2006; Lizano, 2016). Bathypterois longipes was recorded at depths between $2615 \mathrm{~m}$ and $5610 \mathrm{~m}$, however, trawls at these depths are scarce in ECP, even the TALUD 


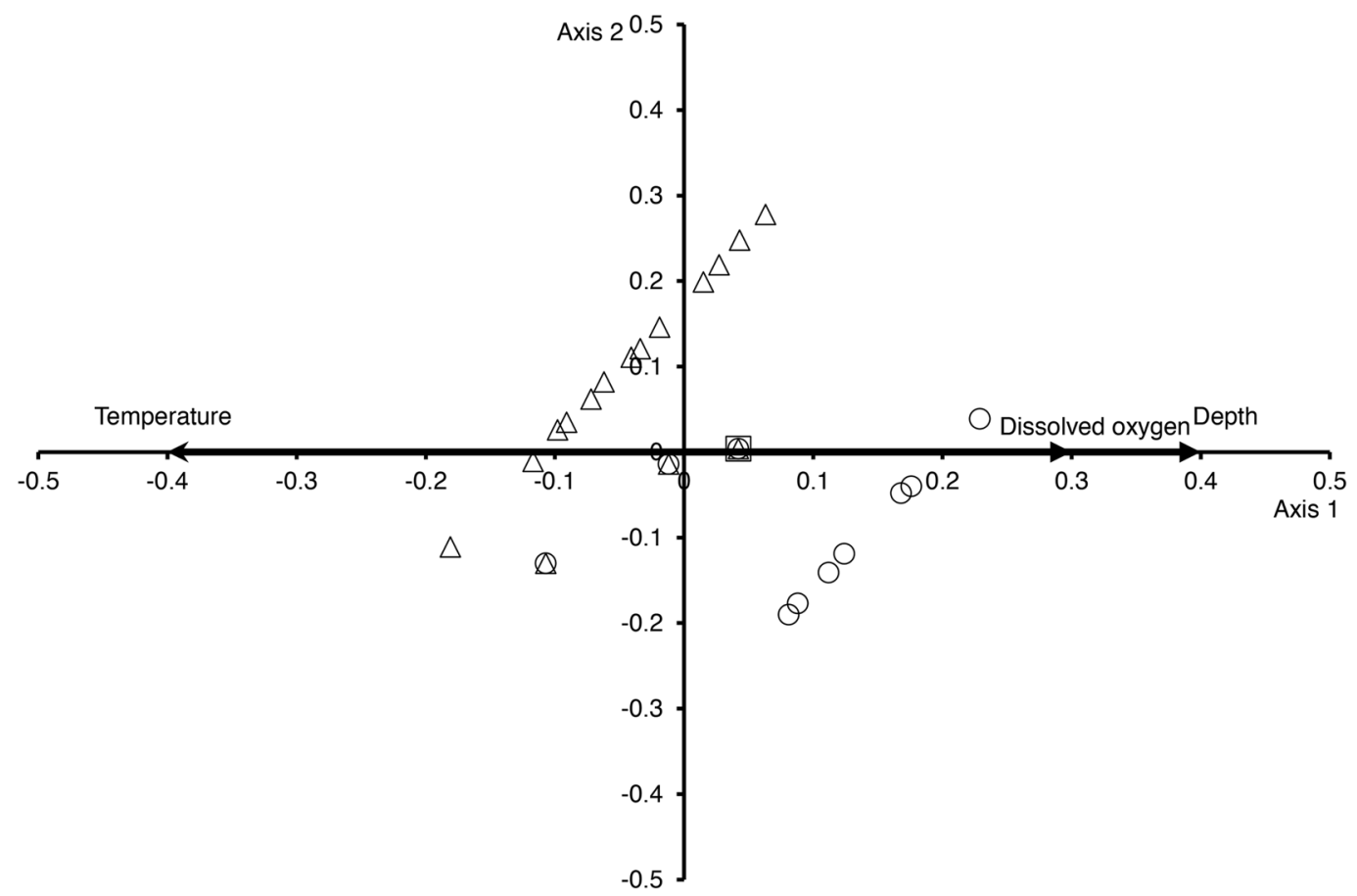

Fig. 6. Canonical correspondence analysis ordination for B. atricolor (open circles), B. ventralis (open triangles) and Bathypterois sp. (open square) records from the TALUD project, respect to environmental factors.

project, so its presence cannot be ruled out in this region. Unfortunately, there are few records regarding to $B$. grallator, $B$. longipes and $B$. pectinatus in relation to environmental factors, so no statistical analysis could be performed. Relating the depth intervals inhabited by these species, B. grallator and B. pectinatus might be able to live in and below the OMZ, while B. longipes could be restricted to sites below the OMZ (Levin, 2003; Hendrickx \& Serrano, 2010).

The boundary of Southern California and Northern Baja California $\left(31^{\circ} \mathrm{N}-33^{\circ} \mathrm{N}\right)$ is an overlapping zone on limits of distribution of many temperate and tropical species, including deep-sea species (Anderson, Tolimieri, \& Millar, 2013). The OMZ between California and Oregon $\left(33^{\circ} \mathrm{N}\right)$, is narrower and starts deeper $(650-1100 \mathrm{~m})$ than the ECP. Phylogenetic and ecological studies suggest that the area of submerged canyons off Los Angeles could be a physical barrier for many species, limiting their distribution to the North (Hickey, 1979; Lynn \& Simpson, 1987; Anderson et al., 2013). The results of this study and the fact that the deep waters off the East coast of USA have been intensively studied (Hubbs, 1960; Anderson, et al., 2013), suggests that the genus Bathypterois is not distributed further North than recorded by the TALUD project.

Bathypterois atricolor and $B$. ventralis showed a unimodal distribution of SL. Possibly, similar to B. mediterraneus in the Mediterranean Sea, there are a differential recruitment between age classes, from shallower waters to the bottom, and a growth markedly reduced in larger specimens (Morales-Nin, Massuti, \& Stefanescu, 1996; Porcu, Follesa, Grazioli, Deiana, \& Cau, 2010). Furthermore, the use of only one sampling method could represent a high selectivity, catching only a few sizes from all available (Pauly, 1984). However, the epibenthic sledge used during the TALUD project was selected because the bottom of the 
Mexican Pacific is rugged and poorly known, which complicates the use of larger trawl nets (Hendrickx, 2012). Records of larvae and juveniles of Bathypterois in plankton and midwater trawls suggest that these species may have differential size or age migrations (Sulak, 1977; Arkhipov \& Simonova, 2012). To describe the population dynamics of Bathypterois species in the ECP, it is necessary to complement the results of this work with seasonal sampling of larvae, eggs and juveniles, including trawls with different mesh sizes and the description of their reproductive biology (Morales-Nin et al., 1996; Porcu et al., 2010).

Bathypterois atricolor and B. ventralis showed a positive allometry without significant differences between their " $\mathrm{b}$ " values $(B$. atricolor: 3.3 ; B. ventralis: 3.5$)$. Bathypterois species use their pectoral fins to settle on the sediment, apparently to feed (Davis \& Chakrabarty, 2011). They need to have negative buoyancy and have suffered a considerable reduction in size and functionality of their swim bladder (Jones \& Sulak, 1990), and to be heavier than water, deep-sea species store high concentrations of lipids in their tissues (Bakes, Elliott, Greens, \& Nichols, 1995). This could be a particular adaptation of the genus Bathypterois for the ECP conditions, which between 800 and $2000 \mathrm{~m}$ depth have temperatures from 2 to $5{ }^{\circ} \mathrm{C}$ and salinities from 33 to 35 , in contrast with the Mediterranean Sea, less dynamic, warmer and salty $\left(10-22^{\circ} \mathrm{C}\right.$, salinity: 36-38), where $B$. mediterraneus has a negative allometric relationships (Catalan Sea: $\mathrm{b}=2.37$; West Ionian Sea: $b=2.81$; Eastern Ionian Sea: $\mathrm{b}=2.82$ ) (Morales Nin et al., 1996; D’Onghia et al., 2004; Watling et al., 2013).

Although the temperature, DO and depth are strongly correlated to each other, the analysis of the effect of each factor alone on distribution of $B$. atricolor and $B$. ventralis, allowed to observe that these species use differently environmental strata available. Bathypterois atricolor had not relationship between SL and environmental factors, but $B$. ventralis had significant correlations for all comparisons, although with low $r$ values $(<40 \%$ of variance explained). Possibly the larger specimens of this species inhabit greater depths than the smaller ones, because of ontogenetic migrations, different diets or environmental requirements (Polloni, Haedrich, Rowe, \& Clifford, 1979).

Bathypterois atricolor had broader environmental niches than $B$. ventralis and both species showed reduced DO niches. Bathypterois atricolor avoided DO concentrations $<0.2$ $\mathrm{mL} / \mathrm{L}$, while $B$. ventralis was restricted to sites with DO concentrations $<1.0 \mathrm{~mL} / \mathrm{L}$. Bathypterois atricolor was distributed inside and outside the OMZ, using broad ranges of depth and temperature, reflected in a greater dispersion of the data in the CCA arrangement. Bathypterois ventralis is an almost permanent resident of the OMZ, using shallower and warmer sites than B. atricolor. Both species are morphologically similar, but their different environmental niches could be related to physiological adaptations, for example differences in hemoglobin concentration and enzymes related to breathing (Levin, 2003). This results and the narrow niche overlap $(<35 \%)$ of all environmental factors suggest that $B$. atricolor and $B$. ventralis use different environmental strata. Despite the limited number of observations available in this work, analyzes were consistent and complementary to effectively describe the environmental niches of B. atricolor and B. ventralis, but further ecophysiological studies are necessary to assess the adaptive differences among them. The adaptation of B. atricolor to live in wide ranges of DO might be an important factor for its nearly circumglobal distribution. Bathypterois ventralis is widely distributed on the EP but has not been recorded in other oceans; possibly its adaptation to live almost permanently in the $\mathrm{OMZ}$ is a limiting factor to have broader geographic and bathymetrical distributions.

\section{ACKNOWLEDGMENTS}

The authors thank Michel Hendrickx, director of the TALUD project, Felipe Amezcua, curator of the Fish collection of the Instituto de Ciencias del Mar y Limnología, Unidad Académica Mazatlán, the academic staff, students 
and crew of the R.V. El Puma who participated in the TALUD cruises. Ship time was provided by the Coordinación de la Investigación Científica, UNAM. This paper was supported by CONACyT project 179467 and partly supported by CONACyT project 243775 . E.C.A. is a recipient of a $\mathrm{PhD}$ fellowship (CONACyT grant 366866).

\section{RESUMEN}

Distribución del género de profundidad Bathypterois (Pisces: Ipnopidae) en el Pacífico Centro Oriental. El género Bathypterois (peces trípode) está conformado por 19 especies de peces de profundidad, distribuidas alrededor del mundo. La biología y distribución de las especies de este género son relativamente poco conocidas a lo largo del Pacífico Centro Oriental (POT). Este trabajo tiene el objetivo de actualizar la distribución geográfica y batimétrica de las especies del género Bathypterois a lo largo del POT. Para describir la influencia de la profundidad, temperatura y concentraciones de oxígeno disuelto (OD) sobre la distribución latitudinal y batimétrica de miembros del género Bathypterois en el Pacífico Mexicano, se analizaron 51 especímenes de $B$. atricolor (12 arrastres) y 112 B. ventralis (18 arrastres), recolectados durante el proyecto TALUD. Bathypterois atricolor presentó nichos ambientales más amplios (profundidad: 0.47 , temperatura: 0.46 , OD: 0.39 ) y habita sitios más profundos y fríos (Electividad positiva: $\left.>1000 \mathrm{~m},<3.2{ }^{\circ} \mathrm{C}, 1.0-1.62 \mathrm{~mL} / \mathrm{L}\right)$ en comparación con $B$. ventralis, que tiene nichos ambientales reducidos (profundidad: 0.34, temperatura: 0.32, OD: 0.28), con alta afinidad por sitios más cálidos y bajas concentraciones de OD (Electividad positiva: $778-1400 \mathrm{~m}, 3.3-5.8^{\circ} \mathrm{C},<1.0$ $\mathrm{mL} / \mathrm{L})$. Estas especies utilizaron distintos estratos ambientales (traslape de nicho; profundidad: 0.34, temperatura: 0.32 , OD: 0.28 ). La adaptación de $B$. atricolor para vivir en un amplio intervalo de concentraciones de OD explica su distribución casi circunglobal, mientras que $B$. ventralis vive casi permanentemente en la Zona de Mínimo Oxígeno $(<0.05 \mathrm{~mL} / \mathrm{L})$, por lo que el OD puede ser un factor limitante, reduciendo su posible distribución geográfica y batimétrica. Ninguna de estas especies había sido registrada anteriormente en el centro del Golfo de California, así como $B$. ventralis no había sido reportada a lo largo de la costa occidental de Baja California. Este estudio confirma que ambas especies tienen una distribución continua dentro del POT, nuestros nuevos registros extienden la distribución más norteña conocida para $B$. atricolor en $886 \mathrm{~km}$ (de $22^{\circ} 46^{\prime} \mathrm{N}$ a $30^{\circ} 45^{\prime} \mathrm{N}$ ) y en $645 \mathrm{~km}$ para $B$. ventralis (de $21^{\circ} 18^{\prime} \mathrm{N}$ a $27^{\circ} 07^{\prime} \mathrm{N}$ ).

Palabras clave: Proyecto TALUD, Pacífico mexicano, factores ambientales, peces trípode, nicho ambiental, análisis univariados y multivariados, distribución.

\section{REFERENCES}

Anderson, M. J., Tolimieri, N., \& Millar, R. B. (2013). Beta diversity of demersal fish assemblages in the North-Eastern Pacific: Interactions of latitude and depth. PlosOne, 8(3), e57918. doi:10.1371/journal. pone. 0057918

Angulo, A., Bussing, W. A., \& López, M. I. (2015). Occurrence of the tripodfish Bathypterois ventralis (Aulopiformes: Ipnopidae) in the Pacific coast of Costa Rica. Revista Mexicana de Biodiversidad, 86(2), 546-549. doi:10.1016/j.rmb.2015.04.025

Arkhipov, A. G., \& Simonova, T. A. (2012). Species Composition and Distributional Pattern of Ichthyoplankton of the Southern Pacific Ocean. Journal of Ichthyology, 52(5), 338-355. doi:10.1134/ s0032945212020026

Bakes, M. J., Elliott, N. G., Greens, G. J., \& Nichols, P. D. (1995). Variation in lipid composition of some deep-sea fish (Teleostei: Oreosomatidae and Trachichthyidae). Comparative Biochemistry and Physiology - Part B: Biochemistry \& Molecular Biology, 111(4), 633-642. doi:10.1016/0305-0491(95)00024-3

Clarke, K. R., \& Warwick R. M. (2001). Change in marine communities: an approach to statistical analysis and interpretation (2nd ed.). PRIMER-E. Plymouth, U.K: PRIMER-E Ltd. Retrieved from http://www.primere.com/Primary_papers.htm

D’onghia, G., Lloris, D., Sion, I., Capezzuto, F., \& Labropoulou, M. (2004). Observations on the distribution, population structure and biology of Bathypterois mediterraneus Bauchot, 1962 in three areas of the Mediterranean Sea. Scientia Marina, 68(3), 163170. Retrieved from http://scimar.icm.csic.es/scimar/ index.php

Davis, M. P., \& Chakrabarty, P. (2011). Tripodfish (Aulopiformes: Bathypterois) locomotion and landing behavior from video observation at bathypelagic depths in the Campos Basin of Brazil. Marine Biology Research, 7, 297-303. doi:10.1080/17451000.2010 .515231

Fiedler, P. C., \& Talley, L. D. (2006). Hydrography of the eastern tropical Pacific: A review. Progress in Oceanography, 69(2-4), 143-180. doi:10.1016/j. pocean. 2006.03 .008

Hendrickx, M. E., \& Serrano, D. (2010). Impacto de la zona de mínimo de oxígeno sobre los corredores pesqueros en el Pacífico mexicano. Interciencia, 35(1), 12-18. Retrieved from http://www.interciencia.org/

Hendrickx, M. E. (2012). Operaciones oceanográficas en aguas profundas: los retos del pasado, del presente y del proyecto TALUD en el Pacífico Mexicano (1989-2009). In P. Zamorano, M. E. Hendrickx, \& M. Caso (Eds), Biodiversidad y comunidades del 
talud continental del Pacífico Mexicano (pp. 23-104). México, D.F: Instituto Nacional de Ecología.

Hickey, B. M. (1979). The California Current Systemhypotheses and facts. Progress in Oceanography, 8(4), 191-279. doi:10.1016/0079-6611(79)90002-8

Hubbs, C. L. (1960). The marine vertebrates of the outer coast. Systematic Zoology, 9(3-4), 134-147. doi: $10.2307 / 2411962$

Jones, A. T., \& Sulak, K. J. (1990). First Central Pacific plate and Hawaiian record of the deep-sea tripod fish Bathypterois grallator (Pisces: Chlorophthalmidae). Pacific Science, 44(3), 254-257. Retrieved from http://hdl.handle.net/10125/1281

Kessler, W. S. (2006). The circulation of the eastern tropical Pacific: a review. Progress in Oceanography, 69(2-4), 181-217. doi:10.1016/j.pocean.2006.03.009

Krebs, C. J. (1999). Ecological Methodology (2nd ed.). Menlo Park, CA: Addison-Wesley Educational.

Lepš, J., \& Šmilauer, P. (2003). Multivariate Analysis of Ecological Data using CANOCO. Cambridge: Cambridge University Press.

Levin, L. A. (2003). Oxygen minimum zone benthos: adaptation and community response to hypoxia. Oceanography and Marine Biology: an Annual Review, 41, 1-45. Retrieved from http://www.crcnetbase.com

Lizano, O. G. (2016). Distribución espacio-temporal de la temperatura, salinidad y oxígeno disuelto alrededor del Domo Térmico de Costa Rica. Revista de Biología Tropical, 64(1), S135-S152. doi:10.15517/rbt. v64i1.23422

Lynn, R. J., \& Simpson, J. J. (1987). The California Current System: The Seasonal Variability of its Physical Characteristics. Journal of Geophysical Research, 92(C12), 12947-12966. doi:10.1029/ JC092iC12p12947

Mendez, N. (2007). Relationships between deep-water polychaete fauna and environmental factors in the southeastern Gulf of California, Mexico. Scientia Marina, 71(3), 605-622. doi:10.3989/ scimar.2007.71n 3605

Morales-Nin, B., Massuti, E., \& Stefanescu, C. (1996). Bathymetric distribution and growth patterns of Bathypterois mediterraneus from the north-western Mediterranean Sea. Journal of Fish Biology, 49(sA): 276-288. doi:10.1111/j.1095-8649.1996.tb06081.x
Palacios-Hernández, E., Beier, E., Lavín, M. F., \& Ripa, P. (2002). The effect of winter mixing on the circulation of the Northern Gulf of California. Journal of Physical Oceanography, 32, 705-728. doi:10.1175/15200485(2002)032<0705:TEOTSV >2.0.CO;2

Pauly, D. (1984). Fish Population Dynamics in Tropical Waters: A Manual for use with programmable calculators. Manila, Phipippines: ICLARM Studies and Reviews, 8, International Center for Living Aquatic Resources Management.

Polloni, P., Haedrich, R. L., Rowe, G., \& Clifford, C. H. (1979). The size-depth relationships in deep ocean animals. Internationale Revue der gesamten Hydrobiologie und Hydrographie, 64(1), 39-46. doi:10.1002/iroh.19790640103

Porcu, C., Follesa, M. C., Grazioli, E., Deiana, A. M., \& Cau, A. (2010). Reproductive biology of a bathyal hermaphrodite fish, Bathypterois mediterraneus (Osteichthyes: Ipnopidae) from the south-eastern Sardinian Sea (central-western Mediterranean). Journal of the Marine Biological Association of the United Kingdom, 90(4), 719-728. doi:10.1017/ S0025315409991330

Rodríguez-Romero, J., Palacios-Salgado, D. S., LópezMartínez, J., Hernández-Vázquez, S., \& Ponce-Díaz, G. (2008). Composición taxonómica y relaciones zoogeográficas de los peces demersales de la costa occidental de Baja California Sur, México. Revista de Biología Tropical, 56(4), 1765-1783. doi:10.15517/ rbt.v56i4.5758

Sulak, K. J. (1977). The systematics and biology of Bathypterois (Pisces, Chlorophthalmidae): With a revised classification of benthic myctophiform fishes. Galathea Reports, 14, 49-108. Retrieved from http:// www.zmuc.dk/InverWeb/Galathea

Watling, L., Guinotte, J., Clark, M. R., \& Smith, C. R. (2013). A proposed biogeography of the deep ocean floor. Progress in Oceanography, 111, 91-112. doi:10.1016/j.pocean.2012.11.003

Zamorano, P., Hendrickx, M. E., \& Toledano-Granados, A. (2006). Distribution and ecology of deep water mollusks from the continental slope, southeastern Gulf of California, Mexico. Marine Biology, 150(5), 883-892. doi:10.1007/s00227-006-0390-5

Zar, J. H. (1999). Biostatistical Analysis (4th ed.). New Jersey, NJ: Prentice Hall. 
